Article

\title{
The Scarecrow as Part of Polish Rural Cultural Landscapes
}

\author{
Karol KróliD \\ Department of Land Management and Landscape Architecture, Digital Cultural Heritage Laboratory, \\ Faculty of Environmental Engineering and Land Surveying, University of Agriculture in Kraków, Balicka 253c, \\ 30-149 Kraków, Poland; k.krol@onet.com.pl; Tel.: +48-126-624-016
}

Received: 22 September 2020; Accepted: 22 October 2020; Published: 24 October 2020

check for updates

\begin{abstract}
Diverse historical, cultural landscapes can be found in many parts of the world, and also in rural areas. They are a challenge for interdisciplinary research. One of the gradually disappearing components of rural cultural landscapes in Poland is the scarecrow. The objective of this paper was to analyse the role of the scarecrow in the Polish rural cultural landscape today. The field research was aimed at determining whether the scarecrow can be seen in Polish rural areas, and if yes, what the circumstances and its forms are. A site visit yielded copious photographic records of rural areas. The investigated area was selected following a literature analysis and analysis of environmental and economic conditions on the regional level in Poland. The visit demonstrated that although scarecrows are part of the cultural landscape of the Polish countryside, they are slightly more modest in their appearance than in the past. Scarecrows are placed in small, family-owned agricultural holdings that have time to uphold local traditions.
\end{abstract}

Keywords: cultural landscape; scarecrows; local traditions; rural areas; cultural heritage

\section{Introduction}

The cultural landscapes of today found coexisting in various parts of the world differ by the origin, degree of transformation, dynamics of metamorphosis, and their determinants. As a result of the centuries-long adaptation and transformation of the natural environment, many locations around the globe offer a diversified mosaic of landscapes with different structures and appearances. They are a challenge for interdisciplinary research, and many attempts were made to classify them using a scientific framework [1].

Traditional landscapes with historical value can be found in many regions, in moderate, subtropical, and tropical climates. Their common characteristic is diversity [2]. This is true also, or rather in particular, for rural areas. Historical rural landscapes, especially those with significant heterogeneity, are often related to traditional ways of farming and considerable biocultural diversity [3]. Rural areas are still dominated by a complex mosaic of land-use types, often similar to the agricultural field mosaic of 19th-century Europe before agricultural industrialisation contributed to monoculture and afforestation [2].

Today, the landscape has gained importance as a vital component of sustainable development. The possibilities of the landscape approach for Europe turn it into a paradigm for new models of development. The paradigm is based on a harmonious integration of social, economic, and environmental factors in time and space. Today's socioeconomic trends are a threat to critical cultural heritage assets. The rural landscape is mostly of historical origin. It requires appropriate assessment and classification followed by preservation and protection. The global trend for cultural globalisation has become noticeable. It often disregards traditional landscape patterns and their long and colourful history [4]. 
The cultural landscape is a landscape transformed by people through civilisational development. The term 'cultural landscape' was first proposed by Friedrich Ratzel in the late 19th century and was popularised by Carl Sauer in English literature to denote all landscapes modified by humans. Cultural landscapes emerge from long-term and complex human-nature interactions, which makes them part of the cultural heritage $[5,6]$.

Almost all European rural landscapes have been shaped or modified by people and can be considered cultural landscapes; many of them are the cultural heritage of high value. The current land management dynamics has put tremendous pressure on cultural landscapes through agricultural intensification and land abandonment. This results in a gradual decline in cultural landscapes. It can be prevented by raising the awareness of the diversity of cultural landscapes and the knowledge about their locations [5].

Studies show that the traditional rural cultural landscape loses its diversity or disappears in many parts of the globe, which entails the loss of many valuable habitats [4,7]. Agricultural holdings intensify production, but often at the expanse of cultural heritage and identity $[5,8]$. Some traditional, historical components of rural landscapes are gone [4]. The scarecrow is involved in many aspects that shape the rural cultural landscape.

Scarecrows have been part of the cultural landscape of the countryside forever. They were a characteristic feature of the rural landscape mostly because they were products of a culture inherently linked to agriculture [9]. Scarecrows appeared in the rural landscape as people started to settle and cultivate land. The first written reports of scarecrows in Polish farms date back to the 16th century. Initially, the role of a scarecrow was assigned to various objects that were believed to have a 'power to scare away' not only animals but also 'evil supernatural forces' [10]. The scarecrow, shaped to resemble the farmer, was placed everywhere were birds and forest animals could threaten crops. They were most often used in kitchen gardens, orchards, or cereal and root crop fields. The landscape of such places was shaped by the farmer, As the farming methods, extents of crops, shifting cultivation, technologies and machinery changed, the role of the scarecrow followed suit [11].

The appreciation grows for the interdisciplinary nature of landscape research, not only in the field of geography and other natural sciences but also in humanities and social and engineering sciences [12]. Moreover, the limited number of studies addressing post-socialist EU member states and the studies addressing specific physical components of landscapes encourage the extension of this area of research [13]. One of the gradually disappearing components of rural cultural landscapes in Poland is the scarecrow, even though it was a common sight not long ago [11]. The objective of the paper was to analyse the role of the scarecrow in the Polish rural cultural landscape today. The field research was aimed at determining whether the scarecrow can be seen in rural areas, and if yes, what the circumstances and its forms are.

This paper is organised as follows. Section 2 provides characteristics of rural areas in Poland contrasted with the same in the European Union. It defines the rural cultural landscape and emphasises that cultural landscapes result from long-term and complex interactions between humans and nature that build cultural heritage. The chapter also covers threats to traditional cultural landscapes. The Section 3 presents the methodological framework with a particular focus on photography as a source of insight into the rules of social, economic, and cultural life. Field research results are presented next. The paper ends with a discussion and conclusions.

\section{Rural areas in Poland and the European Union}

The importance of rural landscapes is recognised at both the international and national level. The cultural nature of European rural landscapes and their origins have been investigated and described well [14-17]. The Old Continent boasts a rich heritage of rural landscapes shaped over thousands of years. Rural cultural landscapes keep evolving while retaining the tokens of their historical origin and performing various social and economic roles. Landscapes classified as rural comprise $95 \%$ of the territory of the EU [18]. Furthermore, $66 \%$ of the EU population lives in rural areas, generating $45 \%$ of 
the gross value of the EU and providing $53 \%$ of its employment. In contrast, agriculture and forestry account for $77 \%$ of land use. Typical features of rural landscapes include long history, traditional ways of life, traditional agricultural practices, typical regional food, a complex and diversified landscape mosaic, and a significant biocultural diversity [17].

The Polish Central Statistical Office (GUS) defines rural areas as areas outside of city/town limits. Still, some 'nonurban' areas, particularly those neighbouring large urban agglomerations, have functional, landscape, and structural features that are more urban than rural. Being in the direct vicinity of urban areas makes rural areas assume typical urban characteristics and function [19]. Some towns, on the other hand, have strong relations with rural areas and many rural traits that make it hard or even impossible to classify them as urban areas. These traits include dispersed structure, relatively low population density, a large share of people working in the agricultural industry, a large number of customer and farmer points of service, or a large share of agricultural and forest land [20]. According to the Rural Development Programme implemented in Poland, rural areas encompass rural municipalities, mixed urban-rural municipalities excluding towns with more than 20,000 inhabitants, and urban municipalities excluding towns with more than 5000 inhabitants [20].

Rural areas cover more than $93 \%$ of Poland and are inhabited by nearly $40 \%$ of the country's population [21]. This high share somehow automatically becomes a source of the causes and effects of differences both at the regional and local level. Development disproportions in rural areas become vividly visible in the places of accumulation of developmental barriers, which derive from the effects of social, economic, environmental, and historical factors [22]. Rural areas in Poland represent $8.3 \%$ of rural areas in the European Union. The share of rural areas in the areas of individual voivodeships is diversified, which is largely due to historical conditions [21].

Over the last 15 to 20 years, many structural changes have taken place in Polish agriculture [13,23,24]. In rural areas in Poland, an increase in the role of non-agricultural production and consumption functions can be seen, at the expense of a decreasing share of agricultural production [21]. Today, rural areas in Poland focus on increasing the number and quality of agricultural machinery, specialisation, and the demographic shift. This has led to monoculture and simplified structure of the rural landscape. Another noticeable consequence is the reduction in arable land and pastures in favour of other land-use types [13]. At the same time, rural development is becoming more sustainable. The multifunctional agricultural model of rural areas is currently one of the basic categories of the policy for agriculture and rural areas in Poland [21]. The changes concerned, among other things, the number of agricultural holdings, crop structure, land area, and livestock population. In 2002, there were 2.9 million agricultural holdings in Poland, while in 2018, the number was 1.4 million. The total area of the agricultural land in 2002 was 16.9 million ha, while in 2018, it was 14.7 million ha [24].

\subsection{Rural Cultural Landscape}

In general, the landscape is a physiognomy of the geographical environment. Originally, the word 'landscape' described a clearing in a forest or next to it, agricultural fields, a cottage with a wooden fence and farm animals or various combinations of such components. It was, generally, a synonym for rural landscape supplemented by forests or wild vegetation. Therefore, the landscape has meant a man-made artefact with associated cultural process values from its very beginning [25]. A much more generic meaning of the landscape is 'a portion of the Earth's surface that can be comprehended at a glance' [26]. The landscape is largely a cultural construct and exists in a state conceived of or to a certain extent 'planned' by people, taking into account its natural components [2].

The landscape can provide abundant information. According to Jackson [27], the landscape can be compared to a richly illustrated book that remains open all the time. All the recipient needs is to know how to read. Hoskins [28] believed that the landscape itself is the most extensive record of history we have if we know how to interpret it correctly. Landscape and memory are inseparable because the landscape is the nerve centre of our personal and collective memories [25]. Places or landscapes reflecting everyday ways of life, the ideologies that compel people to create places, and the sequence 
or rhythm of life over time are significant. They tell the story of people, events and places through time, offering a sense of continuity, a sense of the stream of time. They also offer a cultural context setting for cultural heritage $[25,28]$.

Cultural landscapes are crucial for biodiversity [6]. The concept of cultural landscapes relates to the multifaceted links between people, place, and identity. From a professional perspective, the concept refers to a category of designated conservation areas with specific biocultural heritage values. From a local perspective, it may refer to a landscape that is associated with the provision of a culturally specific sense of identity and belonging [29].

The World Heritage Committee of UNESCO [30] (pp. 13-14) defined cultural landscapes as representing the 'combined works of nature and of man' and 'illustrative of the evolution of human society and settlement over time, under the influence of the physical constraints and/or opportunities presented by their natural environment and of successive social, economic and cultural forces, both external and internal'. According to Rössler [31] (p. 333), cultural landscapes are at the interface of culture and nature, tangible and intangible heritage, biological and cultural diversity-they represent a closely woven fabric of relationships, the essence of culture and people's identity. They are a symbol of the growing recognition of the fundamental links between local communities and their heritage, humankind and its natural environment.

There are three types of cultural landscapes: (1) designed and created landscapes (parks and gardens, often with monuments or historic and cultural buildings); (2) organically evolved landscapes the current form of which has been shaped by anthropogenic factors or interaction with the natural environment, and (3) associative cultural landscapes that evoke religious, artistic, or cultural associations with the use of natural components [32].

Apart from the most inaccessible regions (for example because of topography), most landscapes have been altered by humans. Cultural landscapes grew together with the oecumene. The cultural landscape can be considered, to some degree, as a reflection of evolutionarily improving abilities and opportunities of humans regarding the use and transformation of the environment [33]. Therefore, the landscape can be perceived as a place of continuous interaction between natural processes and human activities [32]. This approach reverberates through the European Landscape Convention, which deems landscapes as results of actions and interactions between naturally occurring processes and anthropogenic impacts [34].

Today's model of agriculture intensification is a threat to traditional agricultural landscapes. It results in 'landscape simplification' and leads to a loss of biodiversity, ecological functions, and critical ecosystem functions in rural areas-hence the importance of the ways in which people perceive the landscape. The perception can affect its structure, especially when the natural environment is treated as a source of resources for economic gains. Farmers perceive the landscape from the perspective of its utility and productivity. Those preferences decrease landscape diversity and deprive it of cultural features [13]. This could account for the gradual decline of such components of the rural landscape that are not effective or productive enough or do not contribute directly to financial results such as scarecrows, which are being replaced by various types of engineered equipment [11].

Maintaining traditional agricultural landscapes is particularly important because the rural landscape is a specific good that has been shaped by agricultural activities [13]. Polish rural areas offer an abundance of historical-cultural landscapes that shape cultural identity and can stimulate the socioeconomic growth of the areas. The rural landscape should be shaped considering components typical of the village, which help identify the space but also aid future activities and projects under a comprehensive vision of development in line with the character of the area. Characteristic components of the village should inspire new objects conforming to new standards but also consistent with the products of the past. 


\subsection{The Scarecrow as Part of the Polish Cultural Landscape}

Wild animals have always posed a threat to crops. The first written reports on scarecrows date back to the Antiquity. As far back as 2500 years ago, the Greeks worshipped Priapus, a god believed to protect wheat fields and grapes. He was the model for the first mannequins placed among crops to repel pests. Bird scaring was practised in Egypt over 3000 years ago as well. Figures resembling humans were put on the banks of the Nile to protect cereals from birds. Japanese documents from before 2500 years also describe customs of repelling animals with mannequins made to look like humans [35].

Scarecrows used to have their place in the Polish rural landscape and were rather common there. They were placed in backyard gardens, agricultural fields, near roads, in orchards, or near vegetable patches. Their job was to scare away wild animals, including wild boar, deer, and fowl [11]. According to folk chronicles, 'many a scarecrow stood in the field. Each smarter than the other. Sometimes, it was hard to tell, was it the farmer straightening his legs or a straw man at his post' [36]. A popular Polish folk term for the scarecrow was dziad, which means a beggar or pauper.

The physique of the scarecrow should resemble a farmer going about his business in the field. To achieve this, it was made of two crossed sticks. In their glory days, the sticks were covered in hay or straw, or rather the (ragged) clothes put on the posts were stuffed with them. All this gave the scarecrow a humanoid form [11].

The scarecrow combined two conflicting realities. On the one hand, it could look daunting, scruffy, dangerous, or even scary in the evening. On the other hand, scarecrows sometimes looked good-natured, which brought positive connotations of a 'kind spirit', guardian, and protector. Therefore, the scarecrow could look both sinister and benevolent. The scarecrow symbolised the folk farming culture and peasants' hope for a good yield [37].

The scarecrow has its traditional regional names in Poland. In Beskid Żywiecki, it is called bebok, in Podkarpackie Voivodeship, dziad or bodo, while some villages use the name mamun, especially for more female-looking scarecrows. Near Nowy Sacz (Beskid Sadecki) and Podhale, it is kulawiec, while areas around Kraków (Małopolskie Voivodeship), people call it puherok [11,37].

There are certain rituals and symbols related to scarecrows. They had a particular role in mountainous regions where it was relatively hard to farm poor-quality land. They guarded small produce that took real effort to farm. The farmer would build the scarecrow at night and place it in the field in secret at the sunrise so that no-one with ill intentions could cast a spell. Such a 'hex' could prevent the scarecrow from doing its job. They were usually placed in the fields in early spring and burnt after harvest. The straw men stood guard near fruit and vegetables if any wildlife was near. Scarecrows were often built in advance and usually with significant care as sometimes farmers had unofficial 'scarecrow contests' [36].

The burning of the scarecrow in the autumn was both pragmatic and metaphysical. The tongues of fire were the end of the sun-faded and wind-torn mannequin. At the same time, the ritual was the pinnacle of the farming season, and the smoke symbolised a human soul fleeing into the clouds [37].

Today, scarecrows are being replaced by modern methods for scaring off wild animals. Growth of developments and human expansion into natural habitats of wild animals resulted in fauna refusing to be scared of human settlements the way it used to be. Hence, the effectiveness of the traditional scarecrow decreased to the extent that some farmers believe them to be of no use [11]. To solve the problem, farmers have intricate digital and mechanical high-tech scarecrows that use IR sensors and ultrasound [38]. 'Digital scarecrows' can have batteries and be powered by solar panels. The latest devices use lasers as well. Laser beams are most often used to scare away birds [39]. Digital technologies are used in smart repellent systems as well [40]. Large fields can have gas cannon scarers. The gun produces a loud bang. It is powered by sun radiation and programmable. Still, digital scarecrows are in a way 'soulless', and most often only specialised holdings can afford them [11]. 


\section{Materials and Methods}

The field research was conducted in Nowosadecki District near Grybów, Nowy Sacz, and Stary Sacz (Małopolskie Voivodeship, Poland; Scheme 1). A site visit yielded copious photographic records of rural areas. Its objective was to find and record (with photographs) scarecrows in a rural landscape. The photographic observations were conducted as an 'external' observer, or outsider. The observation was undisguised and spontaneous but focused; it was directed by the research questions. The investigated area was selected following a literature analysis and analysis of environmental and economic conditions in regions of Poland [11,41].

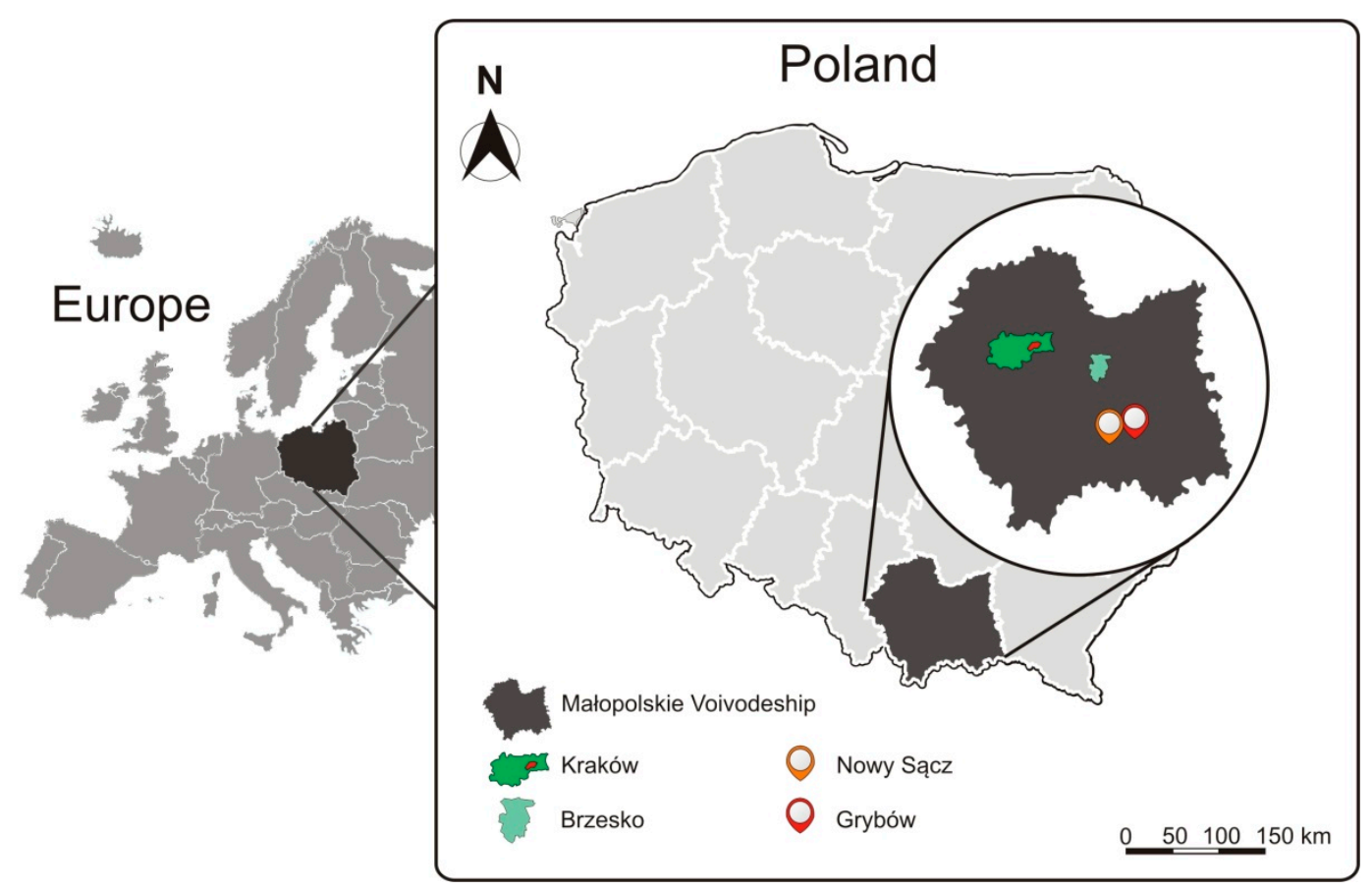

Scheme 1. Site visit area-Grybów, Nowy Sącz, and Stary Sącz (Małopolskie Voivodeship, Poland).

The southern part of Małopolskie Voivodeship consists of mountainous farmland. The topography is diversified with uplands, hills, and rises. It strongly affects how land is used. All this results in significant fragmentation of holdings, which often farm land for internal use or local markets (sale of small amounts of produce, barter, on local marketplaces, or to the next-door neighbour).

The area was selected for the study because of its highland and mountainous topography, which significantly affects land management and agriculture. Grybów is a town in the area of the Góry Grybowskie mountains enclosed by the Kotlina Sadecka valley, and the valley of the Biała. It is the most densely populated part of Beskid Niski because of the towns of Grybów and Gorlice and routes from Grybów to Krynica and from Nowy Sacz to Krosno. At the same time, it has many steep slopes and demanding inclines. Landscape landmarks include the Chełm mountain (779 m ASL) and Pieniny Gorlickie between the villages of Leszczyny and Kunkowa and the Klimkówka reservoir. Nowy Sacz sits in the Kotlina Sądecka valley, which isolates it from other settlements. Stary Sacz is situated on the verge of Beskid Sąecki and is a gateway to the mountains and Zakopane. It is a town in the fork of the Poprad and Dunajec. The valley of Poprad stretches through Ryto and Piwniczna to Muszyna and Krynica, while the Dunajec flows around Beskid Sadecki towards Tatras.

\section{Photographic Records of Rural Areas}

The conceptual framework for the research is based on visual sociology. Visual sociology includes several qualitative techniques that mostly involve analysis and interpretation of visual materials, 
such as photographs, videos, press, and online content. Photography is employed in sociological research in various ways. It can be used as research documentation (photographic records), a stimulus during interviews, or an independent source of information about an object, phenomenon, etc. [42]. Moreover, photographs have great cognitive potential and often help identify important social rules, principles of culture, or social structure.

Photography has become one of the fastest-growing techniques for producing, perceiving, and reproducing images. It can be a medium for a large amount of information and provide complex insights. Photography preserves, shows, and describes reality with images, which facilitates learning and understanding of the world $[43,44]$. Photographed reality can be the perfect material for in-depth analyses, studies, and interpretation. According to Savedoff [45], photography is valued because the audience believes in the accuracy of photographs that document what they depict (objects, events, etc.) and because the objects are thoroughly recorded to reflect their actual appearance. In addition to recording the reality in images, photography is a valuable means of producing documentation. Still, a photograph is not a document in and of itself (not more than any other type of image). Nevertheless, it has documentary value depending on the circumstances [46].

With the support of diverse methodological paradigms, a camera is all but an obligatory tool for ethnographic and folklore research [47]. Photography has been used with success in sociological research [48], but also spatial and landscape ones. Field research often employs various methods for acquiring photographs: auto-photography (self-directed photography) [49], participatory photography [50], repeat photography [51], or aerial photography [52].

Photography is used in investigations of regional trends in land-use change. One of the applicable methods is repeat photography. It involves the comparison of historical and recent landscape photographs from the same camera point. Research shows that the method is both cost- and time-effective when coupled with other field work. It can, therefore, be a useful way of identifying environmental changes to be investigated further [51].

When preparing photographic material, the researcher needs to ask themselves a question of what to photograph, and if to take pictures at all, to obtain an objectively reliable image of objects or events. This aspect is bound to the ethics of preparing photographic material. When taking photographs, one has to keep in mind not only the benefits for the photographer but also the photographed person or occurrence. [53]. According to Byers [54] (p. 31), 'the photograph is not a "message" in the usual sense. It is, instead, the raw material for an infinite number of messages which each viewer can construct for himself.' Edward T. Hall suggested that the photograph conveys little new information but, instead, triggers meaning that is already in the viewer.

The author took photographs of all places where scarecrows were located, with a particular focus on freely accessible spots outside of private property. This way, trespassing was avoided. Several dozen photographs were taken in total. In many cases, it was possible to approach scarecrows and have a close look, especially when they were situated near roads. Freely accessible sites that offered many angles were of much greater research value. The photographs were taken in summer daylight, which was beneficial for image quality. The objective of the photographs was to record the condition of the scarecrows, their structure, and place in which they were placed.

\section{Results}

The field research has shown that scarecrows were placed only near vegetable patches or in kitchen gardens near homes that were not behind a wire fence. There were no scarecrows in larger cereal fields.

Some of the scarecrows resembled a farmer at work. Broad shoulders, waist, and legs were stuffed with straw or hay, and the head wore a cap (Figure 1). Where the scarecrow was made of an old shirt on crossed sticks, it was not possible to tell the sex of the guard (it was more of a 'scarer'), but sometimes they were given female or male features (Figure 1). In such a case, the 'farmer' was accompanied by 
his 'wife'. Scarecrows did not work alone. They can most often be found in pairs or sometimes in groups of a few of them nearby (Figures 1-3).
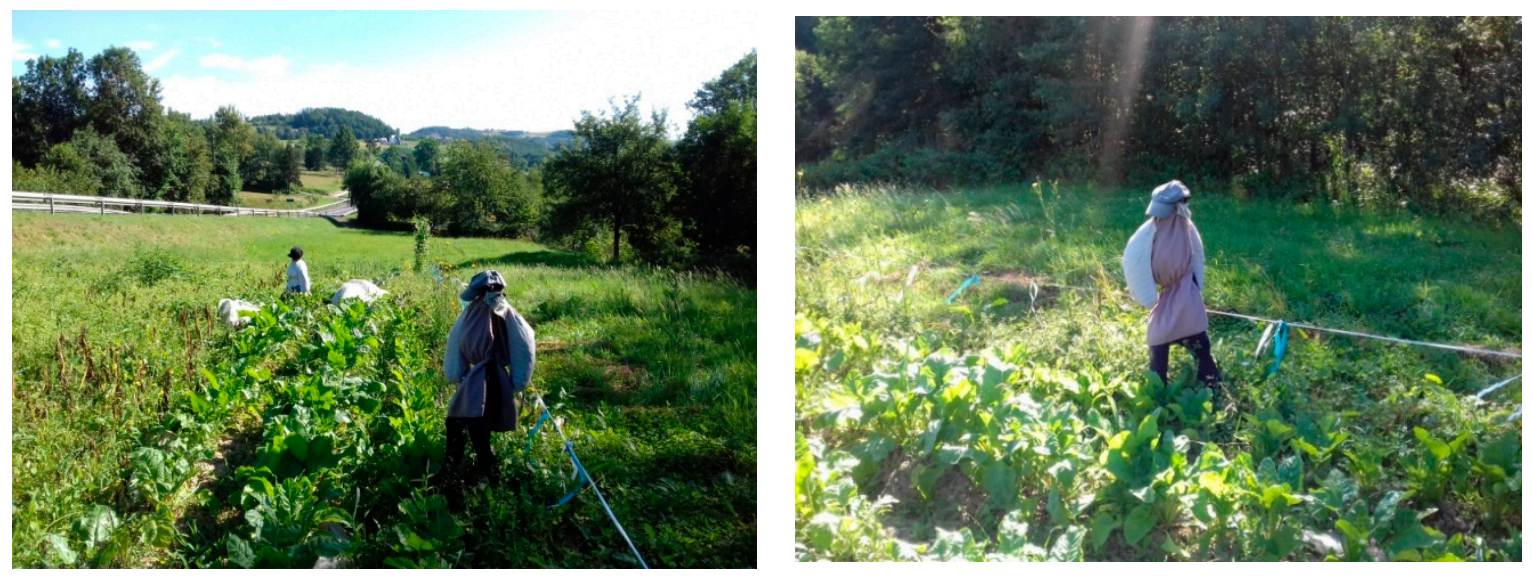

Figure 1. Scarecrows, a 'farmer' and his 'wife' guarding a small vegetable patch. Near Grybów (Małopolskie Voivodeship). Source: author.
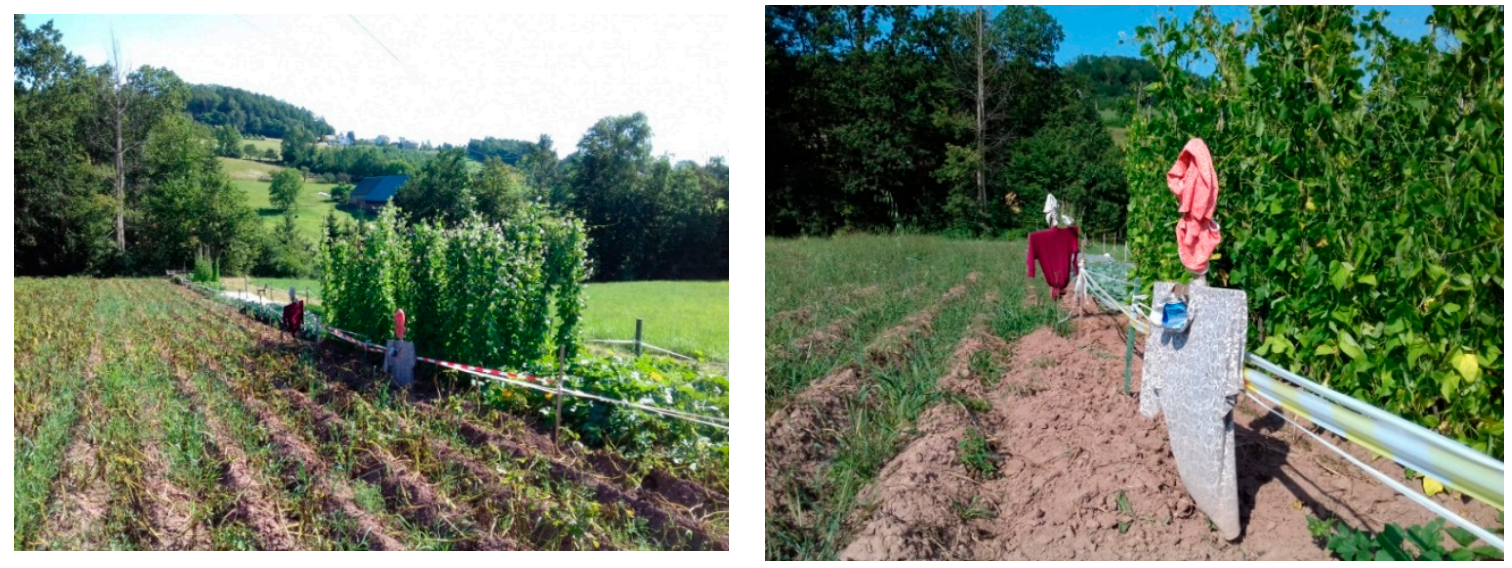

Figure 2. Scarecrows in a potato field, next to vegetables. Near Grybów (Małopolskie Voivodeship). Source: author.
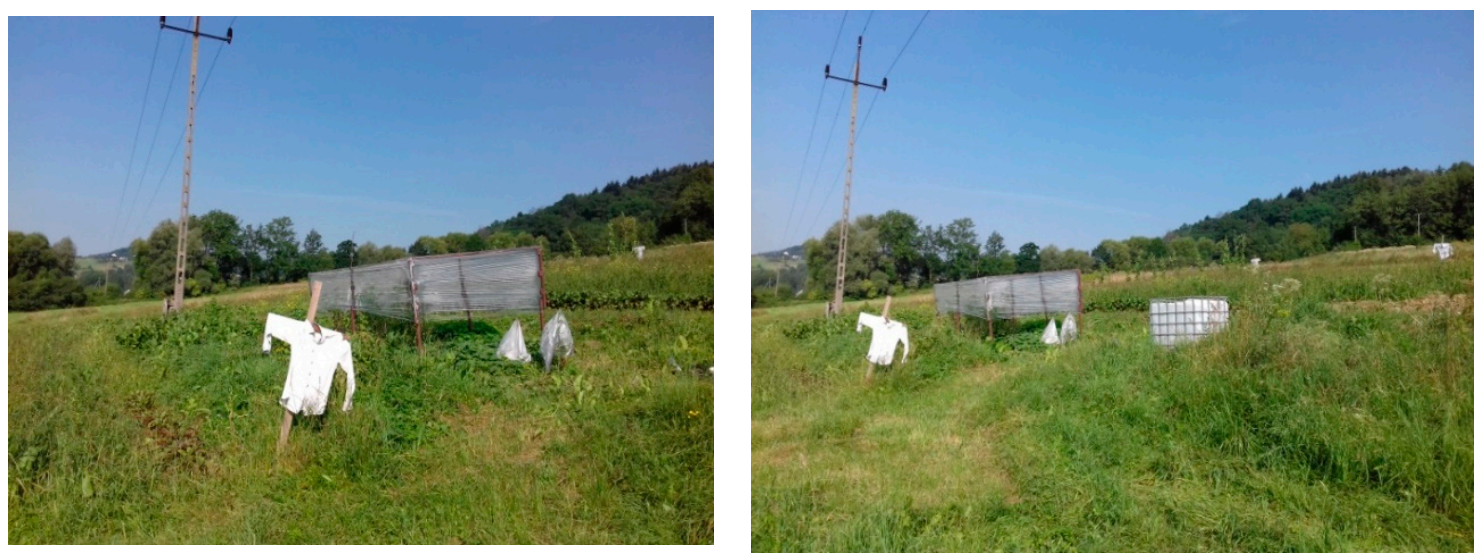

Figure 3. Scarecrows in a vegetable patch. Household cultivation. Near Grybów (Małopolskie Voivodeship). Source: author.

The scarecrows often gave the impression of being forgotten, abandoned, left to themselves, just as the vegetable patches they were looking after (Figure 3). The patches were usually overgrown, 
not weeded, sometimes even incorporated into the 'wild' surroundings (Figure 3). The scarecrows were most often budget structures with an old shirt over a wooden cross (Figures 3-5).
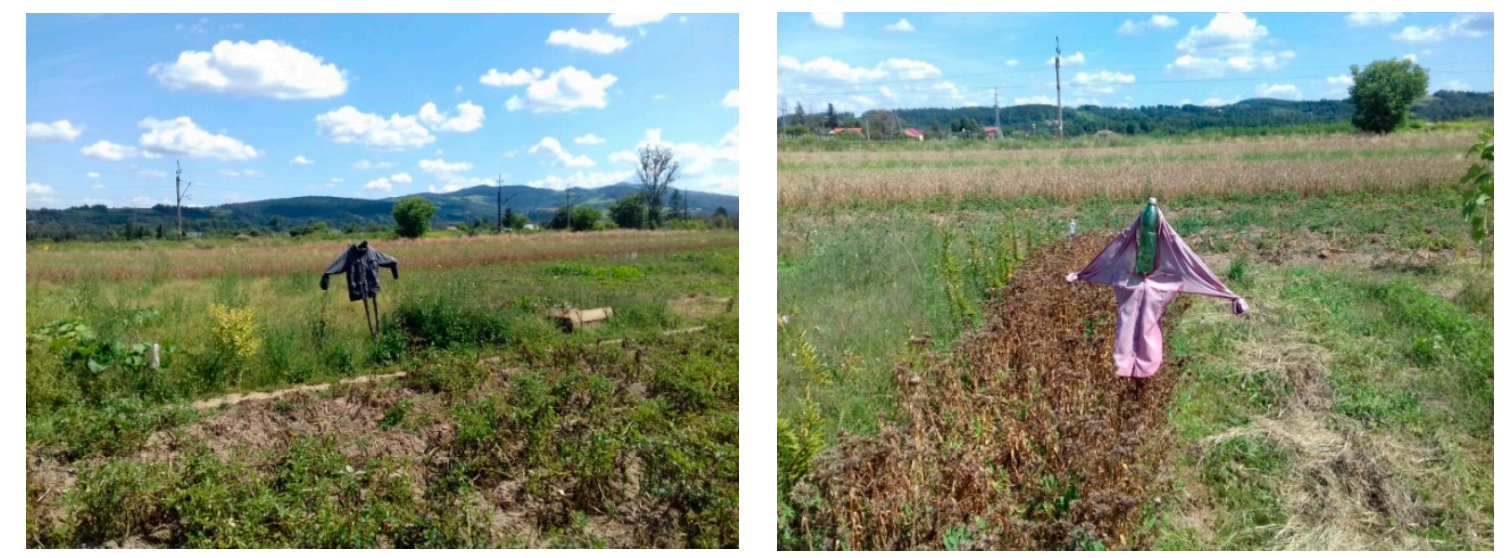

Figure 4. Scarecrows in a vegetable patch. Suburban farming. Near Stary Sącz (Małopolskie Voivodeship). Source: author.
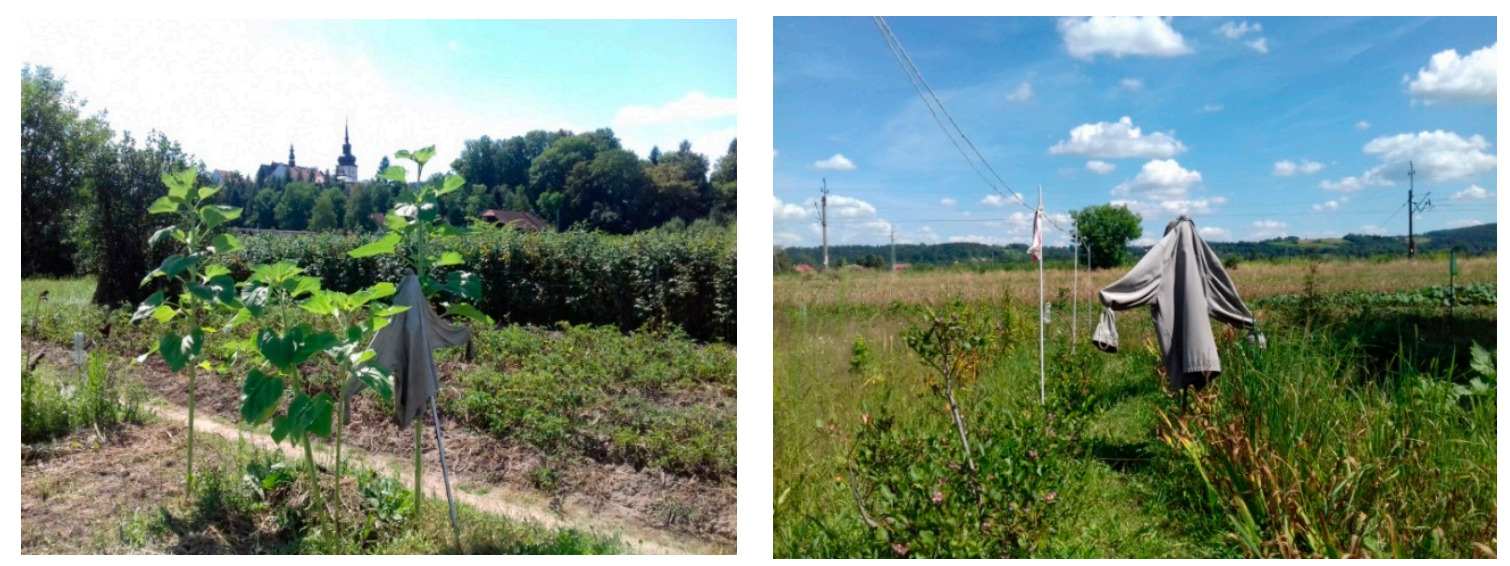

Figure 5. Scarecrows in a vegetable patch. Suburban farming. Near Stary Sącz (Małopolskie Voivodeship).

Source: author.

Nature has no mercy for the scarecrow. Most of the scarecrows were sun-faded, sun-burnt, and nearing collapse (Figures 4-6). There are no more 'beauty contests' for scarecrows, which were so popular in the previous century. The cultural, metaphysical meaning of the scarecrow has been forgotten. Not so long ago, they were carefully built to represent the farmer and make them proud. Scarecrows were noble indeed. They 'fared well' - real 'lords of the manor'. Today, they have fallen into disfavour. They are real 'beggars'. Hardly anybody can be bothered with building them with care and attention. Perhaps the flow of time has ravaged the reputation of the scarecrow. Neither people nor animals respect them. Could this be, perchance, because it no longer looks like an 'actual farmer'? Who will respect 'an old rag on a stick'?

Scarecrows also comprise various ribbons, bands, and cans rattled by the wind (Figure 7). It is hard to say whether they are effective deterrents. 

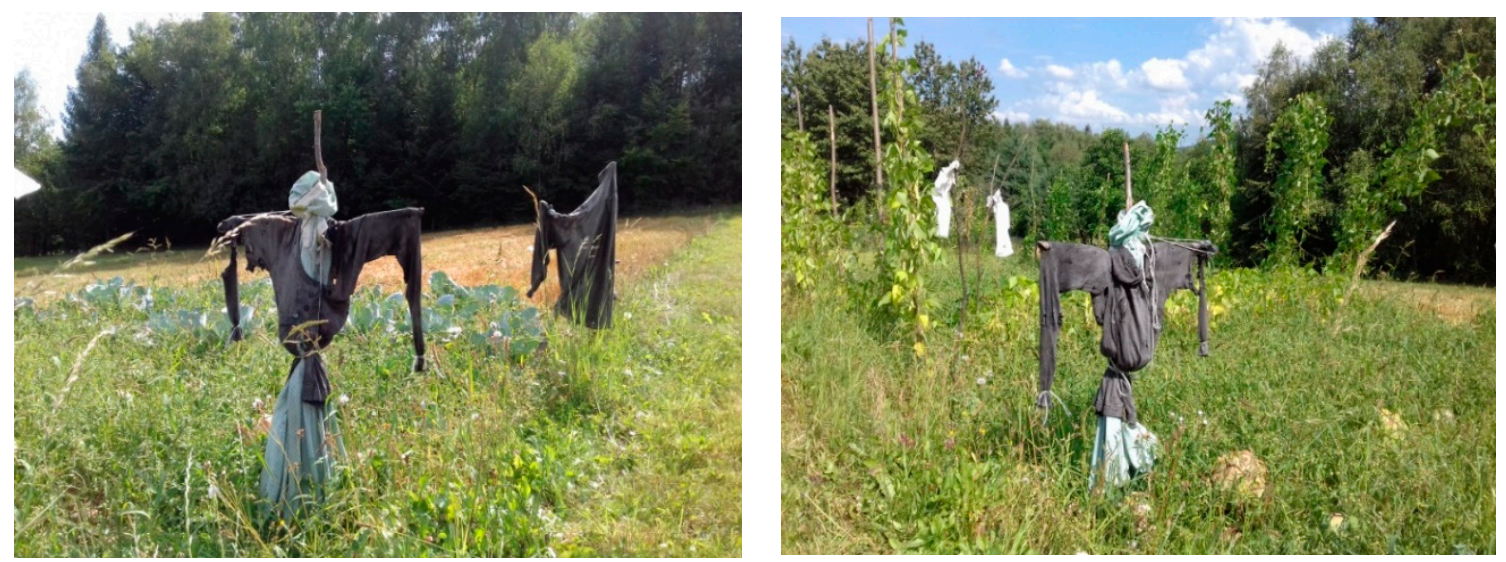

Figure 6. Scarecrows in a vegetable patch. Near Stary Sacz (Małopolskie Voivodeship). Source: author.
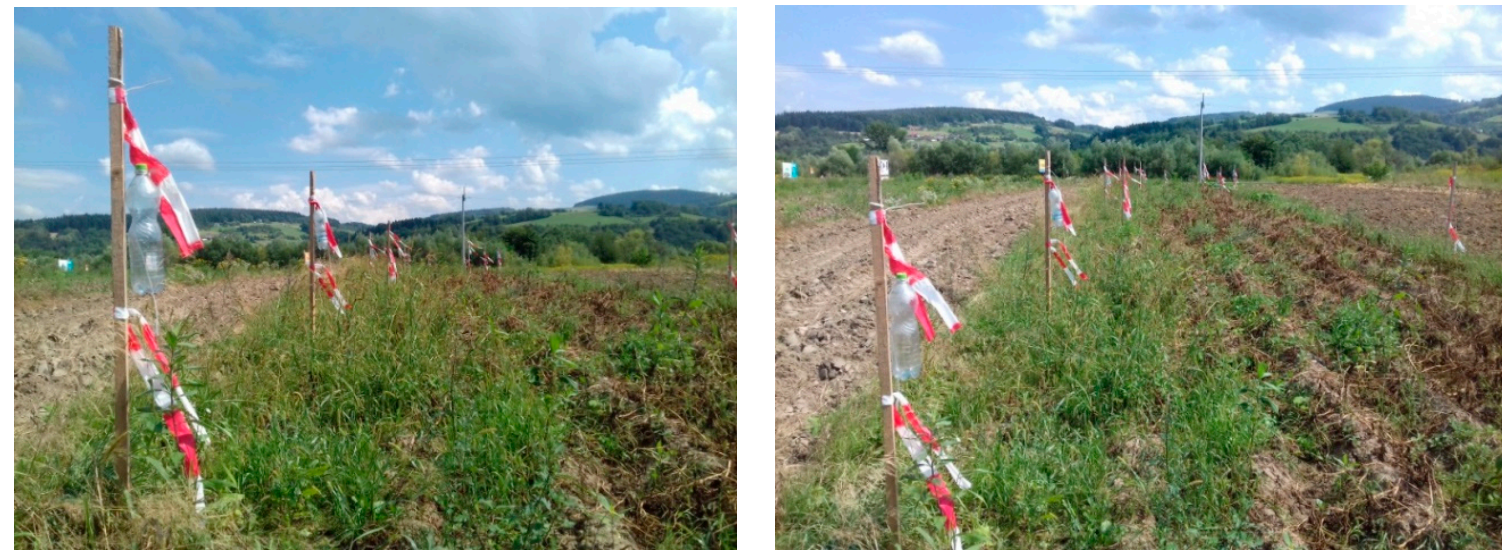

Figure 7. Animal deterrents. A potato field, Stary Sacz (Małopolskie Voivodeship). Source: author.

\section{Discussion}

Agriculture has contributed to the process of shaping typical cultural landscapes all over the world. Regrettably, most of them were lost or degraded in recent decades because of agricultural intensification or setting aside [6,55]. Many researchers believe European cultural landscapes to be threatened $[5,15,55,56]$. The growing demand for food and technological advancement brought about an intensification of farming, in particular in highly productive areas. Less fertile land or land not suitable for intensive agriculture is increasingly often set aside. This approach significantly affects changes in cultural landscapes. Intensified production increases supply but often at the expense of the range of cultural services, including cultural heritage and identity [5]. The same applies to Poland. According to Górka [57], Polish rural areas undergo chaotic spatial changes, and the scale of the landscape visual quality and spatial governance crisis in rural areas grows. Visual destruction of the landscape (as assessed by an observer) has economic, ecological, and social consequences [58]. Significant visual changes take place both in new and old rural developments.

New buildings follow a suburban, universal style, and upgrades to old buildings bereft them of their local character. The way construction plots and homesteads are developed has changed as well. Flower gardens, orchards, or kitchen gardens are being replaced with mowed lawns and hardscaping such as concrete fences, enclosed terraces, fountains, or lighting. This way, typical rural features disappear from the rural landscape even though they prevailed not so long ago [57]. A remedy could be to implement a landscape policy in the form of a collection of strategies, schemes, projects, and innovative actions by state institutions, local and central government agencies, NGOs, and business to protect and create new landscapes that represent high aesthetic values. These actions should be 
aimed at moulding social attitudes regarding the protection and preservation of cultural landscapes as well.

People care about the changing landscape. A survey in Lamole, Chianti (Italy) demonstrated that tourists strongly preferred a traditional landscape consisting of a mosaic of fields with dry-stone terraces and forests, and that the landscape diversification was similar to that from 180 years ago [59]. For Tuscany (Italy), the landscape is the fundamental value from the cultural, economic, environmental, and social perspective [60].

The study demonstrated that the landscape diversity has deteriorated significantly in many places in the world, resulting in reduced biodiversity. The main cause of this is the degeneration of traditional farming and forestry and increased afforestation, in particular in abandoned fields and pastures, which reduces the diversity of the landscape mosaic. The overall trend is towards the degradation of the cultural landscape and its evolution into semi-natural models [61].

Still, the rural landscape is not in retreat everywhere. An Italian study showed that recent years saw no significant changes in the rural landscape. What is more, characteristic features of the historical landscape remained well preserved in 33 areas that had been transformed significantly. This could confirm the resistance to changes these ecosystems exhibit despite the climate and socioeconomic pressure [17].

Research shows that landscape components relevant to agricultural production were of the utmost value for local communities in rural Poland. A lesser value was assigned to components that shape the mosaic of the agricultural landscape. People in rural areas perceive landscape components from an economic perspective. Therefore, the Polish landscape loses habitats believed not to yield direct financial gains such as small ponds, stands of trees amid fields, and boundary strips [13]. This threat to mosaic landscape elements is enhanced by trends in mechanisation, farm enlargement, and specialisation. Researchers forecast the simplification of landscape structure to continue [13]. This puts landscape components that contribute to the ecosystem, regulatory, and auxiliary services in danger [62]. Research shows furthermore that local communities have to be educated regarding non-productive ecological and cultural functions of landscape components [13]. Auer et al. [63] indicated that the landscape is continuously changing, especially when the culture and values of local communities are modified. One of the tools to ensure acceptance for sustainable rural development is to work on the ecological awareness of farmers regarding multifunctional mosaic landscapes and their aesthetic, recreational, protective, and auxiliary functions.

In and of itself, the scarecrow is just a (straw) mannequin made with more or less care. There are many customs and legends related to the scarecrow, but in the end, it is people who ascribe to it all the qualities that place it on the metaphysical plane. Therefore, for some, it is a 'rag on a stick', while for others, a 'mysterious character'. The technological development and growth of digital culture have deprived the scarecrow of its mystical, ominous, and secretive nature to a large extent or even completely, despite its colourful (sinister) depiction in products of popular culture.

According to de Lima [35], the scarecrow combines two aspects, practical and symbolic-magical. It would be hard to separate these functions as the effectiveness of the scarecrow depends on the care and finesse involved in the construction process. If it resembles a man, is colourful, has parts that reflect light, move and make sounds, it is better prepared to deter animals. The 'quality of design' commands respect in passers-by and fuels imagination. Careful construction of a scarecrow, however, takes time, and the tradition is disappearing or has already disappeared. Still, some regions in Poland adhere to it, and some people approach it enthusiastically [11]. Nevertheless, it is considered more of a local tourist attraction or part of territorial marketing than an actual 'ritual' to deter animals. Research shows that the scarecrow is perceived as a cultural heritage asset for older generations of Poles. Still, the youth and middle-aged see it merely as a straw mannequin with no practical purpose of cultural significance [11]. 


\section{The Scarecrow as Part of the Southern Poland Cultural Landscape}

The research shows that the scarecrow is part of the cultural landscape of mountainous areas of southern Poland, which features mostly extensive mountainous farming for internal needs. The process of placing a scarecrow used to be part of Polish rural traditions. It was not practised everywhere but was widely known. The custom was less popular in northern Poland because the area is lowlands. Farmers practise extensive agriculture there, and holdings are larger. Large fields and monoculture are not consistent with the scarecrow tradition, as the farming is mechanised, industrial, or even 'corporate'. The holding management style follows the land use approach. Production should be profitable, mechanised, and managed in modern ways-all this using modern machinery, fertilisers, and plant protection products. There is no room for the scarecrow there. It is completely different in southern Poland, where holdings are smaller.

Mountainous agriculture has its rights. Crops are often cultivated for internal use near the house. Farms are 'family owned'. Such farms use scarecrows made of planks and placed in the kitchen garden, which was reported in the Polish literature [37]. Topography and farming practices helped the scarecrow tradition survive in southern Poland in a more or less live state.

Today, the scarecrow is perceived more as part of the folklore than with its original, deterrent function in mind. This trend is apparent in Poland and globally. The scarecrow is a leitmotif of many festivities and local farming celebrations in the world. The village of Rudzica (municipality of Jasienica, Bielski District, Ślaskie Voivodeship, Poland) celebrates the Scarecrow Day. Part of it is a contest for the most interesting scarecrows. It is held by the Municipal Community Centre in Jasienica. The Wray Scarecrow Festival in northern England has inhabitants produce their own scarecrows. The Stevensville Scarecrow Festival (Ravalli County, MT, USA) follows a similar regime. It is aimed at bringing the local communities closer together. Cleveland (Ohio, USA) holds the East Cleveland Scarecrow Festival, while Wistow (Leicestershire, England) has its Wistow Scarecrow Festival [11]. However, both these events and scarecrows are more ethnographic curiosities with ludic, folkloric, and tourist functions rather than a practical purpose. The scarecrow is remembered but increasingly less used as a way of deterring animals (protecting crops).

It can be seen as leaving the 'practical' domain of agriculture and entering the area of folklore. Note that the 'memory' of the scarecrow is preserved in works of popular culture. The scarecrow has been depicted in films, comic books, or novels, which admittedly have sustained some stereotypes (the scarecrow as an antagonist), but also have kept it in the mind of young generations. The popular culture scarecrow is not the one found in rural landscapes, as it is usually evil. In contrast, the scarecrow was, in fact, a guardian, a protector of the crops.

In a way, scarecrows are put on vegetable patches out of habit. Not only are habits the primary determinant of human behaviour in many areas, but they are also counted among the supports of moral fabric in modern societies [64]. Even if farmers do not believe that scarecrows can effectively protect the field, rural inhabitants still retain some kind of a habit; a habit that may contribute to placing scarecrows 'just in case': 'the cost is negligible and the crop just might be protected'. The tradition of placing scarecrows is handed down less frequently and can disappear as generations change [11].

\section{Conclusions}

The literature suggests that scarecrows should soon completely disappear from the rural landscape. Yet, no such thing has happened. The site visit has demonstrated that there is room for scarecrows in rural areas despite socioeconomic changes. Admittedly, they are relatively modest and no longer regarded as metaphysical objects.

Today, the scarecrow is most often made of old clothes; usually, a worn-out shirt or a peasant 'russet coat' on a wooden cross. This makes the sun-faded, grey figures hard to discern against grey-green natural colours. Sometimes, they stand proudly for a first few weeks of their watch over a potato field or vegetable patch, with the chest swelled with pride and vivid in colour. They display 
vigour and determination in their service. But then, the flow of time, burning sun, and fickle weather come in. Scarecrows make farmers proud at first but are soon forgotten.

No scarecrow stands forever. Every day, they grow more slouched, faded, and wind-torn. All this makes them look as if life was trickling out of them day by day. They go dull, grey, more stooped, and merge with the landscape. Eventually, they grow transparent. Despite this, scarecrows remain part of the Polish rural cultural landscape. This is particularly evident in mountainous areas where scarecrows are placed mostly, or only, in vegetable patches and kitchen gardens. Scarecrows are placed in small, family-owned agricultural holdings that have time to uphold local traditions. They stand guard over fruit and vegetables. Personal-use, low-scale, and extensive farming is characteristic of mountainous areas, and this is where scarecrows are-spotting hills and knolls.

Funding: This study was financed by the Ministry of Science and Higher Education of the Republic of Poland under the project 'Cultural heritage of small homelands' No PPI/APM/2018/1/00010/U/001 financed by the Polish National Agency for Academic Exchange as part of the International Academic Partnerships.

Acknowledgments: The author wishes to express his gratitude to the reviewers for their constructive criticism, which contributed to the final content of the paper. The paper was written at the Digital Cultural Heritage Laboratory, part of the Department of Land Management and Landscape Architecture at the Faculty of Environmental Engineering and Land Surveying of the University of Agriculture in Krakow, Poland.

Conflicts of Interest: The author declares no conflict of interest. The funders had no role in the design of the study; in the collection, analyses, or interpretation of data; in the writing of the manuscript, or in the decision to publish the results.

\section{References}

1. Myga-Piatek, U. Between tradition and modernity of the cultural landscape research discussion on methodology. Methodol. Landsc. Res. 2008, 9, 75-92.

2. Agnoletti, M.; Tredici, M.; Santoro, A. Biocultural diversity and landscape patterns in three historical rural areas of Morocco, Cuba and Italy. Biodivers. Conserv. 2015, 24, 3387-3404. [CrossRef]

3. Agnoletti, M.; Rotherham, I.D. Landscape and biocultural diversity. Biodivers. Conserv. 2015, 24, 3155-3165. [CrossRef]

4. Agnoletti, M. Environmental Thinking and Cultural Values: A Reflection on Environmental Globalisation and the Mediterranean Culture. Glob. Environ. 2014, 7, 257-290. [CrossRef]

5. Tieskens, K.F.; Schulp, C.J.E.; Levers, C.; Lieskovský, J.; Kuemmerle, T.; Plieninger, T.; Verburg, P.H. Characterizing European cultural landscapes: Accounting for structure, management intensity and value of agricultural and forest landscapes. Land Use Policy 2017, 62, 29-39. [CrossRef]

6. Assandri, G.; Bogliani, G.; Pedrini, P.; Brambilla, M. Beautiful agricultural landscapes promote cultural ecosystem services and biodiversity conservation. Agric. Ecosyst. Environ. 2018, 256, 200-210. [CrossRef]

7. Martínez, S.; Ramil, P.; Chuvieco, E. Monitoring loss of biodiversity in cultural landscapes. New methodology based on satellite data. Landsc. Urban Plan. 2010, 94, 127-140. [CrossRef]

8. Plieninger, T.; Kizos, T.; Bieling, C.; Le Dû-Blayo, L.; Budniok, M.-A.; Bürgi, M.; Crumley, C.L.; Girod, G.; Howard, P.; Kolen, J.; et al. Exploring ecosystem-change and society through a landscape lens: Recent progress in European landscape research. Ecol. Soc. 2015, 20, 20. [CrossRef]

9. Lorimer, H. Scaring Crows. Geogr. Rev. 2013, 103, 177-189. [CrossRef]

10. Bielenda, A. Strachy Polne-Dzieje, Rytuat, Symbolika; The Museum of Scarecrows in Lubenia, Communal Public Library in Lubenia: Lubenia, Poland, 2013.

11. Król, K.; Kao, R.; Hernik, J. The Scarecrow as an Indicator of Changes in the Cultural Heritage of Rural Poland. Sustainability 2019, 11, 6857. [CrossRef]

12. Uuemaa, E.; Antrop, M.; Roosaare, J.; Marja, R.; Mander, Ü. Landscape Metrics and Indices: An Overview of Their Use in Landscape Research. Living Rev. Landsc. Res. 2009, 3, 1-28. [CrossRef]

13. Włodarczyk-Marciniak, R.; Frankiewicz, P.; Krauze, K. Socio-cultural valuation of Polish agricultural landscape components by farmers and its consequences. J. Rural. Stud. 2020, 74, 190-200. [CrossRef]

14. Palang, H.; Printsmann, A.; Gyuró, É.K.; Urbanc, M.; Skowronek, E.; Woloszyn, W. The Forgotten Rural Landscapes of Central and Eastern Europe. Landsc. Ecol. 2006, 21, 347-357. [CrossRef] 
15. Agnoletti, M. Rural landscape, nature conservation and culture: Some notes on research trends and management approaches from a (southern) European perspective. Landsc. Urban Plan. 2014, 126, 66-73. [CrossRef]

16. Di Fazio, S.; Modica, G. Historic Rural Landscapes: Sustainable Planning Strategies and Action Criteria. The Italian Experience in the Global and European Context. Sustainability 2018, 10, 3834. [CrossRef]

17. Agnoletti, M.; Emanueli, F.; Corrieri, F.; Venturi, M.; Santoro, A. Monitoring Traditional Rural Landscapes. The Case of Italy. Sustainability 2019, 11, 6107. [CrossRef]

18. Agnoletti, M.; Santoro, A. Cultural values and sustainable forest management: The case of Europe. J. For. Res. 2015, 20, 438-444. [CrossRef]

19. Wilkosz-Mamcarczyk, M.; Olczak, B.; Prus, B. Urban Features in Rural Landscape: A Case Study of the Municipality of Skawina. Sustainability 2020, 12, 4638. [CrossRef]

20. Bański, J.; Mazur, M. Classification of rural areas in Poland as an instrument of territorial policy. Land Use Policy 2016, 54, 1-17. [CrossRef]

21. Rząsa, K.; Ogryzek, M.; Źróbek, R. The Land Transfer from the State Treasury to Local Government Units as a Factor of Social Development of Rural Areas in Poland. Land 2019, 8, 170. [CrossRef]

22. Bartkowiak-Bakun, N. The diversity of socioeconomic development of rural areas in Poland in The Western Borderland and the problem of post-state farm localities. Oeconomia Copernic. 2017, 8, 417-432. [CrossRef]

23. Bański, J. Changes in agricultural land ownership in Poland in the period of the market economy. Agric. Econ. 2011, 57, 93-101. [CrossRef]

24. Piwowar, A. Attitudes and opinions of farmers in the context of environmental protection in rural areas in Poland. Environ. Monit. Assess. 2020, 192, 1-10. [CrossRef] [PubMed]

25. Taylor, K. Landscape and Memory: Cultural landscapes, intangible values and some thoughts on Asia. In Proceedings of the 16th ICOMOS General Assembly and International Symposium: 'Finding the Spirit of Place-Between the Tangible and the Intangible', Quebec City, QC, Canada, 29 September-4 October 2008.

26. Jackson, J.B. Discovering the Vernacular Landscape; Yale University Press: New Haven, CT, USA; London, UK, 1984.

27. Jackson, J.B. Landscape. Human Geography of the Southwest, Berkeley, Calif. 1951. Available online: http://id.lib.harvard.edu/alma/990001139830203941/catalog (accessed on 14 October 2020).

28. Hoskins, W.G. The Making of the English Landscape; Hodder and Stoughton: London, UK, 1955.

29. Cocks, M.L.; Vetter, S.; Wiersum, K.F. From universal to local: Perspectives on cultural landscape heritage in South Africa. Int. J. Herit. Stud. 2017, 24, 35-52. [CrossRef]

30. UNESCO (United Nations Educational, Scientific and Cultural Organization). Operational Guidelines for the Implementation of the World Heritage Convention; UNESCO Intergovernmental Committee for the Protection of the World Cultural and Natural Heritage; WHC 12/01; UNESCO World Heritage Centre: Paris, France, 2012.

31. Rössler, M. World Heritage cultural landscapes. Landsc. Res. 2006, 31, 333-353. [CrossRef]

32. Gordon, J.E. Geoheritage, Geotourism and the Cultural Landscape: Enhancing the Visitor Experience and Promoting Geoconservation. Geosciences 2018, 8, 136. [CrossRef]

33. Andreychouk, V. Evolution of the geographical environment and contemporary geography. Methodol. Landsc. Res. Diss. Comm. Cult. Landsc. 2008, 8, 5-19.

34. Council of Europe. European Landscape Convention; European Treaty Series-No. 176; Council of Europe: Florence, Italy, 2000; Available online: https://rm.coe.int/1680080621 (accessed on 14 October 2020).

35. de Lima, M.R.T. História e estórias do espantalho. Comissão Min. Folc. 2002, 23, 53-69.

36. Szot, S. Iwkowe Kuseryje; Gminna Biblioteka Publiczna w Iwkowej: Iwkowa, Poland, 2008.

37. Bielenda, A. Strachy na wróble [Scarecrow]. In Podkarpackie Centrum Hipoterapii; Biblioteka Akademii Programu Równać Szanse: Błażowa, Poland, 2016.

38. Burns, K. Brainless, Heartless Scarecrows. Yanko Design. Available online: https://www.yankodesign.com/ 2009/04/28/brainless-heartless-scarecrows/ (accessed on 10 October 2020).

39. Homan, H.J.; Slowik, A.A.; Blackwell, B.F.; Linz, G.M. Field Testing Class IIIb Handheld Lasers to Disperse Roosting Blackbirds; National Sunflower Association Sunflower Research Forum: Fargo, ND, USA, 2010.

40. Pornpanomchai, C.; Homnan, M.; Pramuksan, N.; Rakyindee, W. Smart Scarecrow. In Proceedings of the Third International Conference on Measuring Technology and Mechatronics Automation, Shanghai, China, 6-7 January 2011; pp. 294-297. 
41. Solymosi, K. Indicators for the Identification of Cultural Landscape Hotspots in Europe. Landsc. Res. 2011, 36, 3-18. [CrossRef]

42. Pauwels, L. Visual Sociology Reframed: An Analytical Synthesis and Discussion of Visual Methods in Social and Cultural Research. Sociol. Methods Res. 2010, 38, 545-581. [CrossRef]

43. Bohnsack, R. The Interpretation of Pictures and the Documentary Method. Forum Qual. Soc. Res. 2008, 9, 1-24. [CrossRef]

44. Spencer, S. Visual Research Methods in the Social Sciences: Awakening Visions; Routledge: London, UK, 2010.

45. Savedoff, B. Transforming Images: How Photography Complicates the Picture; Cornell University Press: Ithaca, NY, USA, 2000.

46. Rouillé, A. A Photography. In Between Document and Contemporary Art [La Photographie: Entre Document et Art Contemporain]; Gallimard: Paris, France, 2005.

47. Pink, S. Doing Visual Ethnography; SAGE Publications Ltd.: London, UK, 2007.

48. Schwartz, D. Visual ethnography: Using photography in qualitative research. Qual. Sociol. 1989, 12, $119-154$. [CrossRef]

49. Johnsen, S.; May, J.; Cloke, P. Imag(in)ing 'homeless places': Using auto-photography to (re)examine the geographies of homelessness. Area 2008, 40, 194-207. [CrossRef]

50. Kaplan, I.; Miles, S.; Howes, A. Images and the ethics of inclusion and exclusion: Learning through participatory photography in education. J. Res. Spéc. Educ. Needs 2010, 11, 195-202. [CrossRef]

51. Kull, C.A. Historical landscape repeat photography as a tool for land use change research. Nor. Geogr. Tidsskr. Nor. J. Geogr. 2005, 59, 253-268. [CrossRef]

52. Morgan, J.L.; Gergel, S.E.; Coops, N.C. Aerial Photography: A Rapidly Evolving Tool for Ecological Management. Geosciences 2010, 60, 47-59. [CrossRef]

53. Langmann, S.; Pick, D. Dignity and ethics in research photography. Int. J. Soc. Res. Methodol. 2013, 17, 709-721. [CrossRef]

54. Byers, P. Cameras Don't Take Pictures. Columbia Univ. Forum 1966, 9, 27-31.

55. Schulp, C.J.E.; Levers, C.; Kuemmerle, T.; Tieskens, K.F.; Verburg, P.H. Mapping and modelling past and future land use change in Europe's cultural landscapes. Land Use Policy 2019, 80, 332-344. [CrossRef]

56. Vlami, V.; Kokkoris, I.P.; Zogaris, S.; Cartalis, C.; Kehayias, G.; Dimopoulos, P. Cultural landscapes and attributes of "culturalness" in protected areas: An exploratory assessment in Greece. Sci. Total Environ. 2017, 595, 229-243. [CrossRef]

57. Górka, A. Threats to Rural Landscape and Its Protection in Poland. Environments 2018, 5, 109. [CrossRef]

58. Górka, A. Landscape Rurality: New Challenge for The Sustainable Development of Rural Areas in Poland. Procedia Eng. 2016, 161, 1373-1378. [CrossRef]

59. Santoro, A.; Venturi, M.; Agnoletti, M. Agricultural Heritage Systems and Landscape Perception among Tourists. The Case of Lamole, Chianti (Italy). Sustainability 2020, 12, 3509. [CrossRef]

60. Agnoletti, M.; Santoro, A. Rural Landscape Planning and Forest Management in Tuscany (Italy). Forests 2018, 9, 473. [CrossRef]

61. Agnoletti, M. The degradation of traditional landscape in a mountain area of Tuscany during the 19th and 20th centuries: Implications for biodiversity and sustainable management. For. Ecol. Manag. 2007, 249, 5-17. [CrossRef]

62. Alavoine-Mornas, F.; Girard, S. Green belts in the hands and minds of farmers: A socio-agronomic approach to farmers' practices. J. Rural. Stud. 2017, 56, 30-38. [CrossRef]

63. Auer, A.; Maceira, N.; Nahuelhual, L. Agriculturisation and trade-offs between commodity production and cultural ecosystem services: A case study in Balcarce County. J. Rural. Stud. 2017, 53, 88-101. [CrossRef]

64. Camic, C. The Matter of Habit. Am. J. Sociol. 1986, 91, 1039-1087. [CrossRef]

Publisher's Note: MDPI stays neutral with regard to jurisdictional claims in published maps and institutional affiliations. 